\title{
GENETIC STUDY OF HYPOTHENAR PATTERNS ON THE PALM: ESTIMATION OF THE HERITABILITY OF LIABILITY
}

\author{
Kazumichi KaTAYAMA \\ Department of Forensic Medicine, Medical College of Oita, \\ Hasama-cho, Oita 879-56, Japan
}

\begin{abstract}
Summary Palm prints of 349 Japanese families, including 340 pairs of parents and 650 children, were studied with special reference to the inheritance of hypothenar true patterns. It was suggested that the segregation data were more consistent with the hypothesis that hypothenar patternings were transmitted from parents to their children by a multifactorial rather than a simple genetic system. It was demonstrated that individuals with true patterns on both hands had more genetic potential for the patterns than those with unilateral manifestation. The detailed observation of pedigrees revealed that genetic bases corresponding to radial loops and to ulnar loops might be different from each other and that the genes corresponding to radial loops might be related also to the manifestation of carpal loops and whorls. Based on Falconer's method, the heritability values were calculated at $63.9 \pm 9.0 \%$ for the manifestation of radial loops, $75.8 \pm 19.8 \%$ for that of ulnar loops, and $62.8 \pm 10.7 \%$ for the bilateral manifestation of radial loops, indicating a considerably strong genetic determination in hypothenar patternings.
\end{abstract}

\section{INTRODUCTION}

The hypothenar configuration is of extremely variable patterns as compared with the other configurations on the palm. Four primary types of whorls, loops, tented arches, and plain arches and a series of derived varieties have been distinguished there (Cummins and Midlo, 1961), being likely to be "quasi-continuous" variants as finger pattern types. There have been some studies to analyze their heredity and to indicate the genetic control of the presence or absence of the patterns (Weninger, 1947; Holt, 1975; Pons, 1979; Sognier et al., 1979; Floris and Mameli, 1981), but little conclusive information has been obtained regarding the exact modes of inheritance and the degree of genetic determination. This lack of conclusive information may be due to the scarcity of pedigree data to examine intensively.

This paper is concerned with an analysis of the segregation of hypothenar true

Received September 1, 1981 
patterns in 349 Japanese families and an estimation of the heritability, for getting further towards an answer to the question of the relative importance of heredity and intrauterine conditions in palmar dermatoglyphic patternings.

\section{MATERIALS AND METHODS}

The present materials were derived from 349 Japanese families, which were a part of Furuhata's dermatoglyphic collection in the possession of Department of Forensic Medicine, Tokyo Medical and Dental University. There were 650 children falling into 340 sibships with both parents available and 9 sibships without one or both parents. The mean size of sibship was 1.9 and its distribution is given in Table 1. Since the general Japanese samples (Kasai, 1951; Matsui, 1978) showed no sex difference in true pattern frequencies, sex was disregarded for securing a sufficient sample size.

For each palm, the pattern type on the hypothenar area was formulated according to the description of Cummins and Midlo (1961). Materials available for only one hand were not used in the analysis.

The pattern type frequencies (per palm) used here are given in Table 2, where the combinations of true patterns and arches were assigned to the corresponding true pattern and vestiges were incorporated in open/arches. No significant heterogeneity in pattern distribution was found between parents and children. Further, an appreciable deviation was not noticed in pattern type frequencies when compared the present sample with the general Japanese samples (Kasai, 1951; Matsui, 1978).

The calculation of heritability was made by Method 2 in Falconer (1965), using both the regression of parents on their children and that of individuals on their sibs. The Falconer method estimates the heritability of liability to a multifactorial all-ornone trait based on converting the information contained in the incidences into a correlation estimate between relatives. In applying this method, it is assumed that

Table 1. Composition of families in sample.

\begin{tabular}{cccc} 
No. of sibs & No. of families & No. of children & No. of sib pairs \\
\hline 1 & 175 & 175 & 101 \\
2 & 101 & 202 & 120 \\
3 & 40 & 120 & 120 \\
4 & 20 & 80 & 80 \\
5 & 8 & 40 & 45 \\
6 & 3 & 18 & 21 \\
7 & 1 & 7 & 28 \\
8 & 1 & 8 & 515 \\
\hline
\end{tabular}

Jpn. J. Human Genet. 
Table 2. Frequencies of pattern types per hand in present sample.

\begin{tabular}{|c|c|c|c|c|c|c|}
\hline \multirow{2}{*}{ Paîtern type } & \multicolumn{2}{|c|}{ Parents } & \multicolumn{2}{|c|}{ Children } & \multicolumn{2}{|c|}{ Parents + Children } \\
\hline & $\mathbf{n}$ & $\%$ & $\mathrm{n}$ & $\%$ & $\mathrm{n}$ & $\%$ \\
\hline Open/Arches (A) & 1,014 & 75.4 & 933 & 76.6 & 1,947 & 76.0 \\
\hline Tented arches $(\mathrm{T})$ & 1 & 0.1 & 2 & 0.2 & 3 & 0.1 \\
\hline Single loops (Lr) & 289 & 21.5 & 235 & 19.3 & 524 & 20.5 \\
\hline$\left(\mathrm{L}^{\mathrm{u}}\right)$ & 25 & 1.9 & 31 & 2.6 & 56 & 2.2 \\
\hline$(\mathrm{Lc})$ & 5 & 0.4 & 4 & 0.3 & 9 & 0.4 \\
\hline Double loops $\left(\mathrm{L}^{\mathrm{r}} / \mathrm{L}^{\mathrm{u}}\right)$ & 4 & 0.3 & 4 & 0.3 & 8 & 0.3 \\
\hline Whorls $(W+S)$ & 6 & 0.5 & 9 & 0.7 & 15 & 0.6 \\
\hline Total number of palms & 1,344 & & 1,218 & & 2,562 & \\
\hline
\end{tabular}

there is an underlying variable, or liability, normally distributed, determined by multiple environmental and genetic factors with additive effects, and immediately related to the causation of hypothenar patterns, and that, on the scale of liability, there is a point above which the true patterns are present and below which they are absent, or threshold.

\section{RESULTS}

Detailed data on the segregation of hypothenar patterns in the 336 families available for the analysis are presented in Table 3. Further, the combined incidence of all true patterns in the children of different mating types is summarized from Table 3 in Table 4, where the families are arranged in decreasing order of the number of true patterns, i.e., the degree of affectedness, observed in the parents.

It should be noted that a considerable number of children with true patterns on one or both hands were born from quite unaffected parents and that both parents with true patterns could produce children having none. This suggests that hypothenar true patterns are not inherited by a single autosomal dominant or recessive gene with a nearly complete penetrance.

It is obvious that the proportion of affected children increases progressively as their parents have more true patterns, indicating that there is a clear correlation between parents and their children regarding the occurrence of hypothenar true patterns. Only one parental combination disturbed the regularity of the increase in children; in the - $\times$ PP mating type, the number of children with true patterns was unexpectedly high. This disturbance should be noted because of consistency with the results of Weninger (1965) and Morgan et al. (1978). The evaluation is open to examination in the future.

Further, the proportion of the PP children was highest in the PP $\times$ PP combination, lowest in the -- $\times--$ one, and midway in the other parental combinations, 
Table 3. Incidences of hypothenar patterns in children from different mating types

(Sex and laterality not distinguished).

\begin{tabular}{|c|c|c|c|c|c|c|c|c|}
\hline \multicolumn{2}{|l|}{ Parents } & \multicolumn{7}{|c|}{ Children } \\
\hline Crosses & $\mathrm{N}$ & $\mathrm{n}$ & $\mathrm{AA}$ & $A L^{r}$ & $\mathrm{AL}^{\mathrm{u}}$ & LrLr & LrW & Other patterns \\
\hline $\mathrm{AA} \times \mathrm{AA}$ & 146 & 243 & 192 & 31 & 10 & 6 & 0 & $A W, A T^{r}, L^{z} L^{u}, L^{u} L^{u}$ \\
\hline $\mathrm{AA} \times \mathrm{AL}^{\mathrm{r}}$ & 62 & 114 & 87 & 13 & 2 & 11 & 0 & $\mathrm{AA}^{\mathrm{r}}$ \\
\hline $\mathrm{AA} \times \mathrm{LrLr}^{\mathrm{r}}$ & 69 & 136 & 69 & 32 & 4 & 24 & 3 & $A L^{c}, \operatorname{LrTr}, \operatorname{LrLr} / L^{u}, L^{u W}$ \\
\hline $\mathrm{AA} \times \mathrm{ALu}$ & 10 & 16 & 10 & 3 & 2 & 0 & 0 & $\mathrm{LuW}^{\mathrm{u}}$ \\
\hline$A A \times L^{\mathfrak{u}} \mathfrak{u}$ & 4 & 7 & 3 & 0 & 1 & 1 & 0 & $L^{u} L^{\mathfrak{u}}, L^{\mathfrak{u}} A^{r}$ \\
\hline $\mathrm{AA} \times \mathrm{L}^{\mathrm{r}} \mathrm{L}^{u}$ & 2 & 2 & 2 & 0 & 0 & 0 & 0 & \\
\hline $\mathrm{AA} \times \mathrm{AL}^{\mathrm{c}}$ & 4 & 5 & 5 & 0 & 0 & 0 & 0 & \\
\hline $\mathrm{AA} \times \mathrm{AA}^{\mathrm{x}}$ & 1 & 3 & 1 & 1 & 0 & 1 & 0 & \\
\hline $\mathrm{A} A \times \mathrm{AL} / \mathrm{L}^{\mathfrak{u}}$ & 1 & 1 & 0 & 0 & 0 & 1 & 0 & \\
\hline$A A \times L^{r} L x / L^{n}$ & 1 & 1 & 0 & 1 & 0 & 0 & 0 & \\
\hline $\mathrm{AA} \times \mathrm{WL}^{\mathrm{I}}$ & 3 & 3 & 1 & 1 & 0 & 1 & 0 & \\
\hline$A A \times W L r / L^{u}$ & 1 & 4 & 1 & 1 & 0 & 2 & 0 & \\
\hline$A L^{r} \times A L^{r}$ & 6 & 13 & 7 & 2 & 0 & 3 & 0 & $\mathrm{LuLu}^{u}$ \\
\hline$A L^{r} \times L^{r} L^{r}$ & 8 & 12 & 6 & 4 & 0 & 2 & 0 & \\
\hline$A L^{r} \times A L u$ & 1 & 3 & 1 & 0 & 1 & 0 & 0 & LrLa \\
\hline$A L r \times A W$ & 1 & 1 & 1 & 0 & 0 & 0 & 0 & \\
\hline $\mathrm{AL}^{\mathrm{r}} \times \mathrm{AA}^{\mathrm{r}}$ & 2 & 8 & 5 & 1 & 0 & 1 & 0 & $A A^{r}$ \\
\hline $\operatorname{Lr}^{r} \mathrm{r}^{\prime} \mathrm{L}^{r} \mathrm{~L}^{r}$ & 7 & 21 & 5 & 5 & 0 & 8 & 1 & $A A^{x}, A L r / L u$ \\
\hline $\operatorname{LrLr} \times A L^{u}$ & 2 & 7 & 4 & 1 & 0 & 1 & 0 & $A L^{c}$ \\
\hline $\operatorname{LrL}^{r} \times \operatorname{LrL}^{r} u$ & 1 & 2 & 0 & 1 & 0 & 1 & 0 & \\
\hline $\operatorname{LrL}^{r} \times A L^{r} / L^{u}$ & 1 & 2 & 1 & 0 & 0 & 0 & 0 & $\operatorname{L} \subset \mathbf{L} / L^{u}$ \\
\hline $\operatorname{LrL}^{x} \times A L^{c}$ & 1 & 1 & 0 & 0 & 0 & 0 & 1 & \\
\hline $\operatorname{LrLr} \times \mathrm{AT}^{\mathrm{T}}$ & 1 & 3 & 1 & 0 & 0 & 1 & 0 & $\mathrm{LrLe}^{\mathrm{c}}$ \\
\hline $\operatorname{LrLr}^{\mathrm{r}} \times \mathrm{LuW}^{\mathrm{u} W}$ & 1 & 1 & 0 & 0 & 0 & 1 & 0 & \\
\hline Total & 336 & 609 & 402 & 97 & 20 & 64 & 5 & 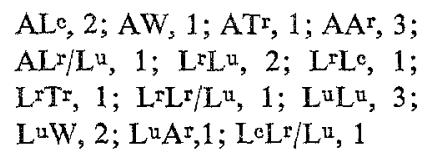 \\
\hline
\end{tabular}

suggesting that individuals with bilateral manifestation have more genetic potential for true patterns than those with unilateral manifestation.

These results may be more consistent with the hypothesis that hypothenar true patterns are caused by a multifactorial rather than a simple genetic system. Moreover, the model assuming two thresholds, i.e., unilateral and bilateral ones, and three phenotypic classes, i.e., absent, present on only one palm, and present on both palms, may be more appropriate to analyzing the inheritance of hypothenar patterns than 


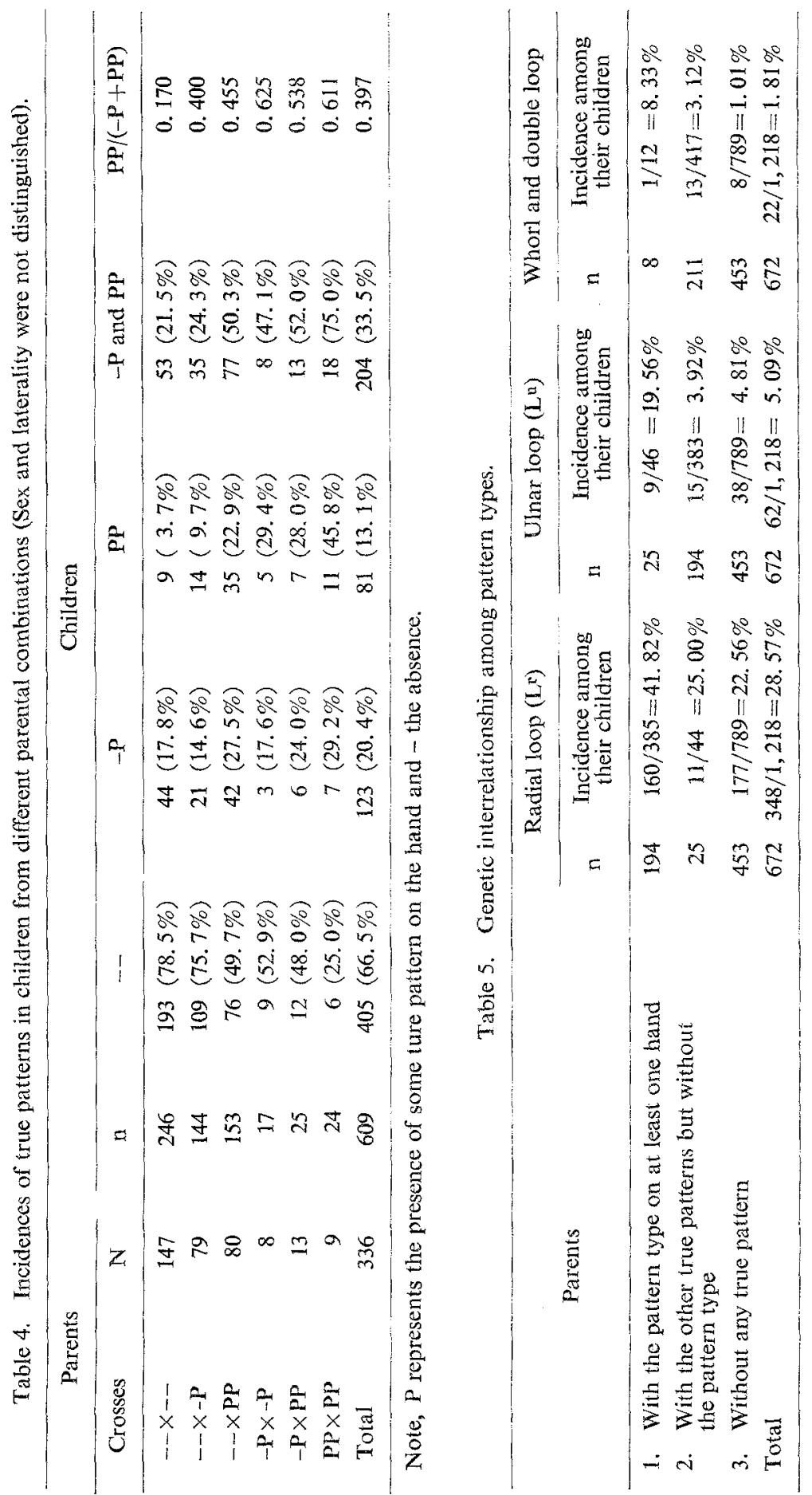


a simple multifactorial model which assumes one threshold and two phenotypic classes, i.e., absent and present on at least one palm.

According to the two threshold model, it is expected from the property of the normal distribution of the underlying variable that, as the overall true pattern incidence $(-P+P P)$ increases, the proportion of bilateral occurrence among the affected individuals will also increase, as pointed out by Ossenberg (1981). In actuality, the ratio of the $\mathrm{PP}$ children to the $-\mathrm{P}$ and $\mathrm{PP}$ ones gradually increases from the - $-\mathrm{X}-$ combination to the $\mathrm{PP} \times \mathrm{PP}$ one, although the $-\mathrm{P} \times-\mathrm{P}$ combination displays a disturbance the cause of which is probably ascribed to a sampling variance due to the small number of children in that combination.

Next, the interrelationship of pattern types was examined with regard to pattern inheritance. The 672 parents were divided into three groups according to the absence or presence of a given pattern type: 1) Those with the pattern type on one or both hands; 2) those with the other pattern types but without the pattern type; and 3) those without any true pattern on both hands. In each group, the incidence of children with the same pattern type on at least one hand was examined, then all children were counted twice. This analysis was impossible for carpal loops $\left(L^{c}\right)$ and tented arches $(T)$ because of their extremely low incidences. As regards $L^{c}$, however, it should be noted that all children with $L^{\circ}$ came from the crosses at least one partner of which had bilaterally $\mathrm{L}^{\mathrm{r}}$ (Table 3 ). Here, W (including $S$ ) and $\mathrm{L}^{\mathrm{r}} / \mathrm{L}^{\mathrm{u}}$ were treated together for the same reason as for the finger pattern classification.

The results are presented in Table 5, where it is shown that, for example, among 385 children coming from 194 parents with $L^{r}, 160(41.82 \%)$ manifested $L^{x}$ on one or both hands. Children with $\mathrm{L}^{\mathbf{r}}$ occurred at a significantly higher rate from parents with $L^{r}$ than from parents without any true pattern $\left(\chi^{2}=24.42, p<0.001\right)$, whereas there was no significant increase in the occurrence of children with $\mathrm{L}^{x}$ among parents with the other true patterns. The situation was also the same for $\mathrm{L}^{\mathrm{u}}$; children with $L^{u}$ occurred at a significantly higher rate from parents with $L^{u}\left(\chi^{2}=14.44, p<0.001\right)$, whereas they occurred at, though not significantly, a rather lower rate from parents with the other true patterns (most of which were $L^{r}$ ) than from parents without any true pattern. For $W$ and $\mathrm{L}^{r} / \mathbb{L}^{u}$, however, a significantly increased occurrence of children with $W$ or $L^{x} / L^{n}$ was found among parents with the other true patterns as compared with those among parents without any true pattern $\left(\chi^{2}=6.66, p<0.05\right)$, although a significance test was not impossible between the children of parents with $W$ or $\mathrm{L}^{r} / \mathrm{L}^{\mathrm{u}}$ and those of parents without any true pattern.

These results suggest that $L^{r}$ and $L^{u}$ are inherited independently, that is, the corresponding genetic bases are different from each other. For $W$ and $\mathrm{L}^{\mathrm{r}} / \mathrm{L}^{\mathrm{u}}$ and perhaps also for $\mathrm{L}^{\mathrm{c}}$, however, there remains a possibility of expressivity, that is, the genes corresponding to $\mathrm{L}^{\mathrm{r}}$ may be related also to their manifestation. Actually, as in the case of $\mathrm{L}^{\mathrm{c}}$, most of the children with $\mathrm{W}$ or $\mathrm{L}^{\mathrm{r}} / \mathrm{L}^{\mathrm{u}}$ ( 9 out of 11 children) had at least one parent with bilateral $\mathrm{L}^{\mathrm{x}}$ (Table 3 ).

In calculating the heritability of liability to a given trait, Method 2 in Falconer 
Table 6. Heritability of liability to hypothenar pattern variations.

A. Based on parent-child data

\begin{tabular}{|c|c|c|c|c|}
\hline Affectibility & $\begin{array}{l}\text { Incidence among } \\
\text { the children of } \\
\text { affected parents }\end{array}$ & $\begin{array}{l}\text { Incidence among } \\
\text { the children of } \\
\text { unaffected parents }\end{array}$ & $\begin{array}{l}\text { Significance of } \\
\text { difference } \\
\left(\chi^{2}\right)\end{array}$ & $\begin{array}{c}\text { Heritability } \\
\text { of liability } \\
(\%)\end{array}$ \\
\hline $\begin{array}{l}\text { 1. Unilateral and bilateral } \\
\text { manifestation of radial } \\
\text { loop }\end{array}$ & $160 / 385=41.56 \%$ & $=22.57 \%$ & $22.78(p<0.001)$ & $63.6 \pm 9.0$ \\
\hline $\begin{array}{l}\text { 2. Unilateral and bilateral } \\
\text { manifestation of ulnar } \\
\text { loop }\end{array}$ & $9 / 46=19.57 \%$ & $53 / 1,172=4.52 \%$ & $16.16(p<0.001)$ & $75.8 \pm 19.8$ \\
\hline $\begin{array}{l}\text { 3. Bilateral manifestation } \\
\text { of radial loop }\end{array}$ & $47 / 207=22.71 \%$ & $85 / 1,011=8.41 \%$ & $27.12(p<0.001)$ & $62.8 \pm 10.7$ \\
\hline \multicolumn{5}{|l|}{ B. Based on sib-sib data } \\
\hline Affectibility & $\begin{array}{c}\text { Incidence among } \\
\text { the sibs of } \\
\text { affected } \\
\text { individuals }\end{array}$ & $\begin{array}{c}\text { Incidence among } \\
\text { the sibs of } \\
\text { unaffected } \\
\text { individuals }\end{array}$ & $\begin{array}{l}\text { Significance of } \\
\text { difference } \\
\left(\chi^{2}\right)\end{array}$ & $\begin{array}{c}\text { Heritability } \\
\text { of liability } \\
(\%)\end{array}$ \\
\hline $\begin{array}{l}\text { 1. Unilateral and bilateral } \\
\text { manifestation of radial } \\
\text { loop }\end{array}$ & $126 / 284=44.37 \%$ & $158 / 728=21.70 \%$ & $27.33(\mathrm{p}<0.001)$ & $74.0 \pm 10.9$ \\
\hline $\begin{array}{l}\text { 2. Unilateral and bilateral } \\
\text { manifestation of ulnar } \\
\text { loop }\end{array}$ & $8 / 42=19.05 \%$ & $34 / 970=3.51 \%$ & $19.69(\mathrm{p}<0.001)$ & $81.8 \pm 20.0$ \\
\hline $\begin{array}{l}\text { 3. Bilateral manifestation } \\
\text { of radial loop }\end{array}$ & $42 / 129=32.56 \%$ & $87 / 883=9.85 \%$ & $35.39(\mathrm{p}<0.001)$ & $85.7 \pm 12.6$ \\
\hline
\end{tabular}

(1965) needs both trait incidences among the relatives of controls and among those of the individuals affected by the trait. These incidences for hypothenar pattern types (obtained from Table 3 ) and the resultant heritability values are shown in Table 6A and $B$ for parent-child data and for sib-sib data, respectively. In both series of data, the heritability was calculated for three kinds of liabilities to; 1) the manifestation of radial loops on at least one hand, 2) that of ulnar loops on at least one hand, and 3) only bilateral manifestation of radial loops. It was impossible to calculate the heritability of liability to bilateral manifestation of ulnar loops and to the other true patterns, since the incidences were extremely low in both parents and children.

For all categories analyzed here, the affected individuals occurred in a significantly increased frequency among the children of the affected parents $(p<0.001)$ and among the sibs of the affected ones $(p<0.001)$. All the six estimates of heritability were similar to one another and considerably large values, between $85.7 \%$ and and $56.6 \%$, indicating that the major part of hypothenar variations depends on a genetic component.

Further, for all the categories, the estimate of heritability was somewhat larger 
from the sib-sib data than from the parent-child data. This increment in the estimate from the sib-sib data may be mainly due to a sibship correlation caused by more common intrauterine factors between sibs than between parent and child. Therefore, the heritability estimate based on the sib-sib data is possibly overestimated and that based on the parent-child data is more appropriate to assessing the amount of genetic influence.

Accordingly, it is concluded that hypothenar patterns, especially radial loops and ulnar loops, are controlled by genetic factors in nearly $60-70 \%$ of their genesis.

\section{DISCUSSION}

Various investigators have produced evidence clearly indicating the presence of genetic factors in hypothenar patternings (summarized in Vrydagh-Laoureux, 1971). With regard to their mode of inheritance, however, there have been some varying suggestions; for example, Weninger (1947) and Pons (1979) assume that hypothenar pattern variations are too complex to be explained by a single-factor inheritance, while Loesch $(1971,1974)$ assumes radial loops to be determined mainly by a single recessive gene and Holt (1975) and Floris and Mameli (1981) assume radial arches to be determined probably by a recessive gene as well. The results obtained here may be interpreted as agreeing with Weninger's assumption and as giving a counter basis for the monogenetic hypothesis of hypothenar patternings.

When compared with the heritability estimate of hypothenar patterns obtained by Loesch $(1971,1974)$, the present one is nearly equivalent to her estimate for radial loops $(50-78 \%$ ) but much higher than her estimate for ulnar loops $(28-30 \%)$. It is impossible to determine the cause for this partial discrepancy. Further, when compared with the heritability estimate of a missing $\mathrm{c}$ triradius obtained by Katayama (1980), the present estimate of hypothenar patterns is smaller, suggesting that the degree of genetic influence differs from one area to another on the palm.

Recently, Ossenberg (1981) has suggested that, in such bilateral nonmetric skeletal traits as mylohyoid bridging and third molar suppression, bilaterally affected individuals have more genetic potential for the traits than unilaterally affected ones, thus more weight should be assigned to bilateral than to unilateral cases in population studies. The present study suggests from the segregation data on hypothenar patterns that the situation may be the same also in bilateral nonmetric dermatoglyphic traits. If so, Kloepfer and Cummins's method which assesses the amount of genetic influence using the "penetrance" concept (Kloepfer and Cummins, 1963) is clearly meaningless. They obtained the "penetrance" values by dividing the number of individuals with the same variants on both hands by the number of individuals with the variants on either one palm or both, on the basis of assuming that bilaterally affected individuals and unilaterally affected ones have the same genetic potential for the variants and that the differentiation is brought about merely by reduced penetrance. Therefore, the "penetrance" values for the missing c triradius (about 30\%) 
by Kloepfer (1977) and for the hypothenar whorls (33.3\%) by Sognier et al. (1979), which were based on a monogenetic hypothesis, are likely to be not appropriate at all.

Some population studies have shown a striking racial variation not only in the frequency of the combined true patterns but also in the relative frequency of radial loops to ulnar loops on the hypothenar area; in Negroids and Caucasoids, hypothenar loops are for the most part of the radial type (Plato and Wereterecki, 1972), whereas, in New Guinea and other Oceanic groups, ulnar loops preponderate (Plato et al., 1972). Such evidence supports the present result that a different series of genes correspond to the manifestation of radial loops and ulnar loops on the hypothenar area.

Acknowledgement The author is indebted to Professor Michio Okajima, Department of Forensic Medicine, Tokyo Medical and Dental University, for his kindness in permitting the author to examine Furuhata's dermatoglyphic collection.

\section{REFERENCES}

Cummins, H., and Midlo, C. 1961. Finger Prints, Palms and Soles. Dover, New York, pp. 100-104. Falconer, D.S. 1965. The inheritance of liability to certain diseases, estimated from the incidence among relatives. Ann. Hum. Genet. 29:51-76.

Floris, G., and Mameli, M. 1981. A further contribution on the hereditary transmission of a particular dermatoglyphic configuration: The radial arch. Dermatoglyphics 9: 2-3.

Holt, B. 1975. The hypothenar radial arch, a genetically determined epidermal ridge configuration. Am. J. Phys. Anthrop. 42: 211-214.

Kasai, K. 1951. Report on the investigation of palmar patterns in 2500 Japanese. Jpn. J. Legal Med. (in Japanese) 5: 140-146.

Katayama, K. 1980. Genetic study of missing c triradius on the palm: Estimation of the heritability of liability. Jpn. J. Hum. Genet. 25: 23-27.

Kloepfer, H.W. 1977. A genetic model for the inheritance of a dermatoglyphic trait: Absence of the palmar c-triradius. In Dermatoglyphics. An International Perspective (J. Mavalwala ed.), World Anthropology Series, Mouton, The Hague. pp. 223-230.

Kloepfer, H.W., and Cummins, H. 1963. Norms and heritability of palmar dermatoglyphics. Proc. Sec. Int. Congr. Hum. Genet. Roma, 1961 3: 1491.

Loesch, D. 1971. Genetics of dermatoglyphic patterns on palms. Ann. Hum. Genet. 34: 277-292.

Loesch, D. 1974. Genetical studies of sole and palmar dermatoglyphics. Amn. Hum. Genet. 37: 405-421.

Matsui, I. 1978. Dermatoglyphics and congenital abnormalities. Shoni-Igaku (in Japanese) 11: $814-868$.

Morgan, L.Y., Juberg, R.C., and Faust, C.C. 1978. The inheritance of palmar and hallucal dermatoglyphic patterns in fifty-four American Caucasian families. Am. J. Phys. Anthrop. 49: 441-448.

Ossenberg, N.S. 1981. An argument for the use of total side frequencies of bilateral nonmetric skeletal traits in population distance analysis: The regression of symmetry on incidence. Am. J. Phys. Anthrop. 54: 471-479.

Plato, C.C., and Wereterecki, W. 1972. A method for subclassifying the interdigital patterns: A comparative study of the palmar configurations. Am. J. Phys. Anthrop. 37: 97-110.

Plato, C.C., Brown, P., and Gajdusek, D.C. 1972. Dermatoglyphics of the Micronesians from the Outer Islands of Yap. Z. Morph. Anthrop. 64: 29-44. 
Pons, J. 1979. Genetics of dermal ridges: Pattern inheritance in the hypothenar area. Birth Defects: Original Article Series XV (6): 539-542.

Sognier, M.A., Kloepfer, H.W., and Cummins, H, 1979. The inheritance of the hypothenar whorl. Birth Defects: Original Article Series XV (6): 543-555.

Vrydagh-Laoureux, S. 1971. Hérédité des dermatoglyphes. Bull. et Mém. de la Soc. d'Anthrop. de Paris 7 : 281-305.

Weninger, M. 1947. Zur Vererbung der Hautleistenmuster am Hypothenar der menschlichen Hand. Mitt. Anthrop. Ges. Wien 73: 55-82,

Weninger, M. 1965. Dermatoglyphic research. Hum. Biol. 37: 44-56. 